\title{
An Analysis of the Relevancy between the Effect on Stock Price by Merger and the Value of Merger Option and/or Synergy Effect ${ }^{*}$
}

\author{
Masaya Okawa ${ }^{\mathrm{a}, \dagger}$ and Wenjie $\mathrm{Ma}^{\mathrm{b}}$ \\ ${ }^{a}$ Yanmar Co., Ltd. \\ ${ }^{\mathrm{b}}$ Finance Research Center, Shanghai University of Finance and Economics
}

\begin{abstract}
This paper examines the effect of Mergers on the capital market by real options and synergy effects. First, using event studies, we find that there are significant positive effects of merger announcements on stock prices. The effects of merger announcements between non-group companies are stronger than that between group companies. Then, with cross section analysis, we find that there isn't significant relationship between the merger announcements effects and synergy effects, but there is positive significant relationship between the merger announcements effects and merger option value in case of merger between non-group companies.
\end{abstract}

Keywords: Merger options; synergy effects; event study; merger announcement; real option

\footnotetext{
* Received: July 11, 2009; Accepted: January 29, 2010.

${ }^{\dagger}$ Corresponding author. Address: 1-32 Chayamachi, Kita-ku, Osaka 530-8311, Japan; Phone: +81-6-6376-6215; E-mail: roptionm@mx2.canvas.ne.jp
} 


\title{
合併の株価効果と合併オプション価値 ・ シナジ一効果価値の 関係についての実証分析
}

\author{
大川 雅也 ${ }^{\mathrm{a}}$ ，馬 文傑 ${ }^{b}$ \\ a ヤンマー株式会社 \\ $\mathrm{b}$ 上海財経大学 金融学院 現代金融研究中心
}

\section{1 はじめに}

ファイナンス研究において，M\&A の経済性分析は，主として M\&A がもたらす買収企業と被買 収企業の株主価值への影響と企業業績に与える影響に対する分析がなされてきた. 分析方法と しては，イベント・スタディとパフォーマンス・スタディがある.イベント・スタディは M\&A 前後の株価効果から合併の経済性を分析する方法で, パフォーマンス・スタディは M\&A が企業 業績に与える影響を計測することから M\&Aの経済性を分析する方法である.

M\&A に関するこれまでの研究の多くは，M\&Aが実施された後の経済的価值，すなわち，M\&Aに 対する市場の反応を観測することにより, M\&A が株主価值に与える影響について検討している. 理論研究では, 1970 年代に, Levy and Sarnat [18], Lewellen [19], Higgins and Schall [12]や Haugen and Langentieg [11]らにより, M\&A による企業のレバレッジの変化を通じた株価への影響に関す る研究が中心に行われた. 1980 年代になると, 株主と経営者の対立関係や経営者の心理に着目 し, M\&A の株価効果に関する研究が盛んに行われるようになった. 代表的な研究としては, Amihud and Lev [1], Jensen [14], Roll [27], Shleifer and Vishny [29]らがある．実証研究について は，イベント・スタディによる M\&A アナウンスメント日における株価効果に関する研究を中心 として多くの報告がなされている. 代表的な研究としては, Bradly, Desai and Kim [6, 7], Jarrell, Brickley and Netter [13], Lang, Stulz and Walkling [17], Morck, Shleifer and Vishny [23], Mann and Sicherman [20], Servaes [28], Berkovitch and Narayanan [3], Kang, Shivdasani and Yamada [15], Mulherin and Boone [25], Andrade Mitchell and Stafford [2], Yeh and Hoshino [31], 井上 [32], 井 上・加藤 [33]らが挙げられる.

これら M\&A がもたらす企業価值, あるいは株主価值への影響を分析する研究に対して, 近年, リアルオプション理論を用いて M\&A 戦略の経済的価值を明らかにしょうという研究が行われて いる．設備投資と同様に，M\&A 投資を投資意思決定問題として捉え企業戦略遂行によって生ま れるシナジー効果の価值や M\&A 実施のタイミングを分析している. 理論研究には, Smith and Triantis [30], Betton and Moran [4], Lambrecht [16], Morellec and Zhdanov [24], Okawa and Tsujimura [26]らがある. 実証研究としては，大川・辻村 [34]，大川 [35]，Dunis and Klein [10]がある.

しかしながら, 先行研究では, 合併取引の経済価值に関する理論研究は行われているものの, 
実証研究においては，買収企業と非買収企業でアナウンスメント効果に対する株価効果の違い を研究しているものがほとんどであり, 合併取引そのものの経済効果に関する研究は筆者の知 るところほとんどない．また，日本の株式市場においては日本固有の問題である親子上場の問 題がある. 日本企業の合併に関する先行研究では, グループ戦略の変更に伴う上場子会社の上 場廃止のための合併について分析を行っている実証研究も筆者の知るところほとんどない.

本稿は，M\&A の中でも最も不可逆性が大きい合併の経済的価值に関する実証研究である．合 併とは，買収企業および被買収企業の経営者が，別々に事業を行うより統合して事業を行うほ うが，企業価值の増大が見込まれると予測できる場合に，企業の所有権である株式の取得によ るコーポレート・コントロールの移転を行う投資取引であり, 結合による規模の経済, 垂直統 合の経済，補完的な資源の活用，非効率性の排除，節税効果の活用拡大，余剩資金の有効活用， 負債キャパシティの利用，市場参入の時間短縮，市場支配力の増大や将来の戦略的アドバンテ ージの獲得などのシナジーを通じた両企業の企業価值・株主価值の最大化を追求しようとする 経営者の行動である. シナジー効果は, 合併が無い場合の 2 つの企業の時価総額の和と合併後 の新しい企業の時価総額の差として表すことができる.つまり, 合併とは, シナジ一効果の価 值の最大化を目的とした, 合併が無、場合の 2 つの企業の時価総額を合併後の新しい企業の時

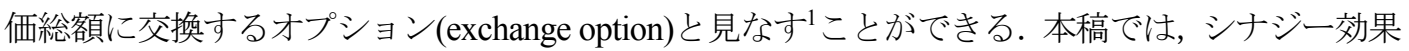
価值の最大化を目的とした交換オプションの価值を合併オプション価值という.

本稿の目的は，合併取引そのものに対する株式市場の反応を観測とその要因分析である. 具 体的には, 1988 年以降に実施された合併をサンプルとし, 合併アナウンスメントに対する株式

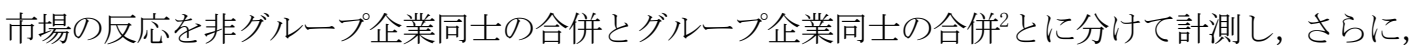
合併アナウンスメント時点での合併オプションの価值と合併後のシナジー効果の価值により分 析しようというものである。まず，合併する 2 つの企業の株式時価総額の合計額を用いて，イ ベント・スタディにより合併発表日における株主価值への影響，すなわち異常収益率を算出す る. 次に，合併する 2 つ企業の合併発表日以前の株式時価総額の合計額を用いて，マーケッ トモデルにより合併が無いと仮定した場合の合併実施時点（上場廃止時点）における株式時価 総額を推定する. この推定した株式時価総額を行使価格, 合併発表後の 2 つの企業の株式時価 総額の合計額を原資産として, リアルオプション・アプローチを用いて合併オプションの価值 を算出する．さらに，合併実施後に統合してできた企業の株式時価総額とマーケットモデルに より推定した合併が無いと仮定した場合の合併実施時点（上場廃止時点）における株式時価総 額からシナジー効果の価值を算出する. 最後に, 算出された合併オプションの価值とシナジー 効果の価值を用いて，合併発表日時点での株主価值への影響を分析する．分析に当たっては， 当該合併がグループ企業同士の合併か，非グループ企業同士の合併かに分けて分析を行う.

本稿の貢献は 3 つある. 1 つはイベント・スタディに関する点で，先行研究では買収企業と 非買収企業のそれぞれの異常収益率を計測し合併アナウンスメントの株価効果を議論している のに対し，本稿では買収企業と非買収企業の株式時価総額の合計額を利用して異常収益率を計

1 交換オプション(exchange option)については, Margrabe [21], McDonald and Siegel [22], Carr [9]が詳し い.

2 本稿では, 企業グループ全体での非買収企業の株式保有比率が $20 \%$ 以上ある合併をグループ企業同士 の合併， $20 \%$ 未満を非グループ企業同士の合併とする. 
測し，合併そのものの株価効果を検証している点である. 2 つ目がイベント・スタディによる 合併の株価効果の要因を合併オプション価值とシナジー効果価值により分析している点である. 3 つ目が合併を非グループ企業同士の合併か，グループ企業同士の合併かに分けて合併の株価 効果とその要因を分析している点にある.

本稿の構成は以下の通りである．第 2 節でイベント・スタディの方法，合併オプション価值 の算出方法およびシナジー効果価值の算出方法について述べた後, 合併オプション価值の算出 に用いる行使価格の推定方法について述べる．第３節では，分析に使用するサンプルおよびデ 一タについて述べた後，分析結果を示す．最後に，第 4 節で結語を述べる.

\section{2 分析方法}

\section{1 イベントスタディ}

合併アナウンスメントの株価効果を検証するために，合併する企業の株式時価総額の合計值 に対する異常収益率 (abnormal return; 以下異常収益率) を分析する. 以下, Campbell and Mackinlay [8]を参考として，本稿のイベント・スタディの方法を説明する. 尚，イベント・スタディの方 法の説明に際して，特段の断りがない限り合併する企業の株式時価総額の合計值を株式，東証 1 部上場企業の時価総額を市場と呼ぶ.

合併アナウンスメント日をイベント日であると考える. 時点 $\tau$ をイベント毎に考え, イベン 卜発生日を $\tau=0$ とする. $\tau=0$ の前後の期間を, 推定ウィンドウ (Est W)，イベント・ウィン ドウ $\left(\right.$ Event W)，イベント後ウィンドウ (Post Event W)の 3 期に分ける. Est W として, $\tau=T_{1}+1$

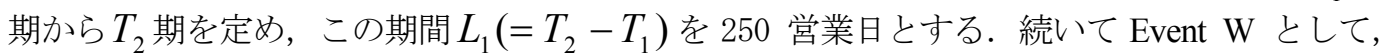
$\tau=T_{2}+1$ 期から $T_{3}$ 期を定め, この期間を $L_{2}\left(=T_{3}-T_{2}\right)$ とする. 具体的には合併アナウンス メント日の前後各 3 営業日を取り, $L_{2}=7$ 営業日とする. この時, $r=0 \in\left[T_{2}+1, T_{3}\right]$ であ る.

次のマーケットモデルを考える.

$$
\begin{aligned}
& R_{i}=X_{i} \theta_{i}+\varepsilon_{i}, \\
& E\left[\varepsilon_{i} \mid X_{i}\right]=0, \varepsilon_{i}: N\left(0, \sigma_{\varepsilon_{i}}^{2}\right)
\end{aligned}
$$

ここで, $R_{i}=\left[R_{i T_{1}+1}, \cdots, R_{i T_{2}}\right]^{\prime}$ は，Est W における株式 $i$ の収益率の $L_{1} \times 1$ のベクトルであ る. $X_{i}$ は $L_{1} \times 2$ の行列で，第 1 列はすべての要素が 1 のベクトル，第 2 列は市場の収益率の ベクトル $R_{m}=\left[R_{m T_{1}+1}, \cdots, R_{m T_{2}}\right]^{\prime}$ である. $\theta_{i}=\left[\alpha_{i}, \beta_{i}\right]^{\prime}$ は $2 \times 1$ のパラメータ・ベクトルであ る.

一般的な条件および $(1)$ 式の仮定から， $\theta_{i}$ の最小二乗推定量 $\hat{\theta}_{i}$ は一致性と有効性を持つ. $\hat{\theta}_{i}$ を使って Event W における予測を行ったときの予測誤差を以下のように推定する. 


$$
\hat{\varepsilon}_{i}^{*}=R_{i}^{*}-X_{i}^{*} \hat{\theta}_{i}
$$

ここで, $R_{i}^{*}=\left[R_{i T_{2}+1}, \cdots, R_{i T_{3}}\right]^{\prime}$ は, Event W における株式 $i$ の収益率の $L_{2} \times 1$ のベクトルで ある. $X_{i}^{*}$ は $L_{2} \times 2$ の行列であり, 第 1 列はすべての要素が 1 のベクトル, 第 2 列は市場の収 益率のベクトル $R_{m}^{*}=\left[R_{i T_{2}+1}, \cdots, R_{m T_{3}}\right]^{\prime}$ である. $\hat{\varepsilon}_{i}^{*}$ が異常リターンのベクトルである.

「合併アナウンスメントは株価の収益率に影響を与えない」という帰無仮説 $H_{0}$ を考える. $H_{0}$ の下で, $X_{i}^{*}$ を条件付けた $\hat{\varepsilon}_{i}^{*}$ の分布は次の正規分布に従うと考えて良い.

$$
\begin{aligned}
& \hat{\varepsilon}_{i}^{*} \sim N\left(0, V_{i}\right), \\
& E\left[\hat{\varepsilon}_{i}^{*} \mid X_{i}^{*}\right]=0, \\
& V_{i}=E\left[\hat{\varepsilon}_{i}^{*} \hat{\varepsilon}_{i}^{*^{\prime}} \mid X_{i}^{*}\right]=I \sigma_{\varepsilon_{i}}^{2}+X_{i}^{*}\left(X_{i}^{\prime} X_{i}\right)^{-1} X_{i}^{*^{\prime}} \sigma_{\varepsilon_{i}}^{2} .
\end{aligned}
$$

ここで $I$ は, $L_{2} \times L_{2}$ の単位行列である.

次に, 異常リターンを各株式について集計する。このとき, 各 Event W の歴時間が重なつ ていないように取る. すると, 各 Event W における異常リターンは独立であるとみなすこと ができる.

合併アナウンスメントの数を $\mathrm{N}$ とする. 以下, 各株式について合併アナウンスメントが一回 ずつ行なわれたという前提の下で説明を進める. まず，株式 $i$ につて Event $\mathrm{W}$ 内の異常リタ ーンを集計する. $\gamma$ を要素がすべて 1 の $L_{2} \times 1$ ベクトルとし, Event $\mathrm{W}$ における株式 $i$ の累積 異常リターンを $\widehat{C A R}_{i}\left(T_{2}, T_{3}\right)$ と表し,

$$
\widehat{C A R}_{i}\left(T_{2}, T_{3}\right)=\gamma^{\prime} \hat{\varepsilon}_{i}^{*}
$$

と定義する.（3）より， $H_{0}$ 下で，

$$
\begin{aligned}
& \widehat{C A R}_{i}\left(T_{2}, T_{3}\right) \sim N\left(0, \sigma_{i}^{2}\left(T_{2}, T_{3}\right)\right), \\
& \sigma_{i}^{2}\left(T_{2}, T_{3}\right)=\operatorname{Var}\left[\widehat{C A R}_{i}\left(T_{2}, T_{3}\right)\right]=\gamma^{\prime} V_{i} \gamma
\end{aligned}
$$

となる。

次に, $\widehat{C A R}$ を標準化した $\widehat{S C A R}$ 


$$
\widehat{\operatorname{SCAR}}_{i}\left(T_{2}, T_{3}\right)=\frac{\widehat{C A R}_{i}\left(T_{2}, T 3\right)}{\hat{\sigma}_{i}\left(T_{2}, T_{3}\right)} .
$$

を考える. $H_{0}$ の下で, $\widehat{\operatorname{SCAR}}_{i}\left(T_{2}, T_{3}\right)$ は自由度が $\left(L_{2}-2\right)$ の $t$ 分布に従い，その分散は $\left(L_{2}-2\right) /\left(L_{2}-4\right)$ となる. $L_{2}$ が十分大きいとき, $\widehat{S C A R}\left(T_{2}, T_{3}\right)$ は正規分布で近似できる.

Event W における各異常リターンが独立していることを利用し, 各株式について平均した統 計量

$$
\begin{aligned}
& \overline{\operatorname{CAR}}\left(T_{2}, T_{3}\right)=\frac{1}{N} \sum_{i=1}^{N} \widehat{\operatorname{CAR}}_{i}\left(T_{2}, T_{3}\right), \\
& \overline{\operatorname{SCAR}}\left(T_{2}, T_{3}\right)=\frac{1}{N} \sum_{i=1}^{N} \widehat{\operatorname{SCAR}}_{i}\left(T_{2}, T_{3}\right)
\end{aligned}
$$

を考える.

$H_{0}$ の下で, $\overline{\operatorname{SCAR}}\left(T_{2}, T_{3}\right)$ は平均が 0 , 分散が $\left(L_{2}-2\right) /\left(N\left(L_{2}-4\right)\right)$ の正規分布で近似で きる. これを標準化すると, 次の検定統計量 $J$ を得る.

$$
J=\left(\frac{N\left(L_{2}-4\right)}{L_{2}-2}\right)^{0.5} \overline{\operatorname{SCAR}}\left(T_{2}, T_{3}\right) .
$$

検定には， $H_{0}$ の下で， $J$ が漸近的に標準正規分布に従うことを利用する.

\section{2 合併オプション価値の算出方法}

合併オプションとは, 合併が無い場合の 2 つの企業の株式時価総額を合併後にできる新しい 企業の株式時価総額に交換する意思決定と見なせることから，交換オプション(exchange option) として定式化できる. 合併後の株式時価総額を原資産 $V(t)$ とし, シナジ一効果が含まれるプロ セスとする，合併アナウンスメント日までの情報（株式時価総額）に基づいて，仮に合併が行 われない場合として推定した株式時価総額を行使価格 $I(t)$ と寸る.つまり, シナジ一効果を考 慮しない場合の合併時点での株式時価総額の推定值を行使価格とする. 行使価格の推定方法に ついては 2.4 項で詳しく述べる. 合併オプション価值を $C(t)$ とすると, 合併が害施される時刻 $T_{M}$ における合併オプションの境界条件は,

$$
C\left(T_{M}\right)=\max \left[V\left(T_{M}\right)-I\left(T_{M}\right), 0\right]
$$

で与えられる.

(11)式を同值マルチンゲール測度の下で期待値を取り, リスクフリーレートで現在価值に割り 
引くことにより合併オプション価值が求まる. 本稿では次のブラックショールズモデルを用い て合併オプション価値を算出する.

$$
\begin{aligned}
& C(\tau)=V(\tau) N\left(d_{1}\right)-I\left(T_{M}\right)^{-r\left(T_{M}-\tau\right)} N\left(d_{2}\right) \\
& d_{1}=\frac{\ln \left[V(\tau) / I\left(T_{M}\right)\right]+(r+\sigma / 2)\left(T_{M}-\tau\right)}{\sigma \sqrt{T_{M}-\tau}} \\
& d_{2}=d_{1}-\sigma \sqrt{T_{M}-\tau}
\end{aligned}
$$

ただし， $\tau$ は現在時点 $\tau=0$ で，合併アナウンスメント日を表す． $\sigma$ はボラティリティで一定 と仮定する. ボラティリティ $\sigma$ は，シナジー効果を含むプロセスを採用するため，合併後に実 現した株式時価総額のデータにより推定する. この場合, 合併後の株式時価総額には合併オプ ション価值が含まれていないため, シナジー効果のみが残っていることになり, ボラティリテ イ $\sigma$ を一定と仮定しているので, 合併後の株式時価総額データに基づいて推定した $\sigma$ をシナジ 一効果のみを含むプロセスのボラティリティとして利用可能となる，r $r$ 無リスク金利で CD3 ケ月物金利を用いる. $N(\cdot)$ は標準正規分布関数である.

\section{3 シナジ一効果価値の算出方法}

合併がなされると合併オプションは消滅するため, 合併後の株式時価総額にはシナジー効果 が含まれ，その価值を $V\left(T_{M}+1\right)$ とする. 以下のマーケットモデルを推定する.

$$
\begin{aligned}
& V_{i t}=\beta_{i 0}+\beta_{i 1} R_{M t}+\eta_{i t} \\
& t=T_{M+1}, \cdots, T_{M+250}
\end{aligned}
$$

但し， $V_{i t}$ は合併取引 $i$ が時点 $t$ における合併後の株式時価総額であり， $R_{M t}$ は $t$ 時点における 市場収益率であり， $\beta_{i 0}, \beta_{i 1}$ は係数である. (13)式を用いて, 推定ウィンドウの終日 $(\tau-4)$ か ら合併の翌日 $T_{M+1}$ までの日々の期待収益率を求め, それらを $R_{\tau}^{\prime}, t=\tau-3, \cdots, T_{M+1}$ とする.

合併アナウンスメント日以前においては，市場には合併に関する情報が織り込まれていない ため合併オプション価值もシナジ一効果も含まれていない. 推定ウィンドウの終日 $(\tau-4)$ にお ける両企業の株式時価総額の合計額を $V(\tau-4)$ とする. シナジ一効果は以下のように計算する ことができる.

$$
\text { synergy }=\ln \left(\frac{V\left(T_{M}+1\right) E_{T_{M+1}}\left[\exp \left(-R_{\tau-3}^{\prime}\right)\right] \cdots E_{T_{M+1}}\left[\exp \left(-R_{T_{M+1}^{\prime}}^{\prime}\right)\right]}{V(\tau-4)}\right)
$$

3 詳しくは Black and Scholes [5]を参照されたい. 
ただし，

$$
\begin{aligned}
& E_{T_{M+1}}\left[\exp \left(R_{t}^{\prime}\right)\right]=\exp \left(\hat{\beta}_{i 0}+\hat{\beta}_{i 1} R_{M t}\right) E_{T_{M+1}}\left[\exp \left(\eta_{i t}\right)\right] \\
&=\exp \left(\hat{\beta}_{i 0}+\hat{\beta}_{i 1} R_{M t}+\frac{1}{2} \sigma_{\eta_{i t}}^{2}\right), \quad t=\tau-3, \tau-2, \cdots, T_{M+1}
\end{aligned}
$$

\section{4 行使価格の推定方法}

シナジー効果が含まれない場合の合併時点における株式時価総額を行使価格として推定する. すなわち，合併アナウンスメント日までの情報（株式時価総額）に基づいて，合併時点の株式 時価総額を推定する. まず，（1）式のマーケットモデルを用いてパラメータ $\hat{\theta}_{i}^{*}$ を求める. 次に 次式を用いて推定ウィンドウの終日 $(\tau-4)$ から合併日 $T_{M}$ までの日次の期待収益率を求める.

$$
E_{\tau-4}\left(R_{i t}\right)=X_{i t}^{*} \hat{\theta}_{i}^{*}, \quad t=\tau+1, \tau+2, \cdots, T_{M}
$$

$E_{\tau}$ は $\tau$ 時点までの情報に基づいた条件付期待值オペレーターであり， $X_{i t}^{*}$ は(1)式において $t$ 時 点の説明変数を表す. 最後に，(15)式で求めた日次の条件付期待収益率を用いて，合併時点に おける株式時価総額を次の通り推定する.

$$
\begin{aligned}
E_{\tau-4}\left[I\left(T_{M}\right)\right] & =E_{\tau-4}\left[I\left(T_{M}-1\right) \exp \left(R_{T_{M}}\right)\right] \\
= & E_{\tau-4}\left[I(\tau-4) \exp \left(R_{\tau-3}\right) \cdots \exp \left(R_{T_{M}}\right)\right] \\
= & I(\tau-4) E_{\tau-4}\left[\exp \left(R_{\tau-3}\right)\right] \cdots E_{\tau-4}\left[\exp \left(R_{T_{M}}\right)\right]
\end{aligned}
$$

ただし，

$$
\begin{aligned}
E_{\tau-4}\left[\exp \left(R_{t}\right)\right] & =\exp \left(X_{i t} \theta_{i}\right) E_{\tau-4}\left[\exp \left(\varepsilon_{t}\right)\right] \\
= & \exp \left(X_{i t} \theta_{i}+\frac{1}{2} \sigma_{\varepsilon_{t}}^{2}\right), \quad t=\tau-3, \tau-2, \cdots, T_{M}
\end{aligned}
$$

\section{3 データサンプおよび分析結果}

\section{1 データサンプル}

本稿の分析に使用した取引サンプルは, 1988 年 1 月 1 日から 2005 年 12 月 31 日までに発表 された合併で，かつ，2006 年 12 月 31 日までの期間に取引が完了した上場企業同士の合併をサ ンプルとした。 この内， 2006 年 12 月 31 日までに合併が完了していない取引，買収企業あるい は被買収企業の発行済株式数の増減日が特定できない取引, 途中で合併が取り止めとなった取 引をサンプルから除いた。 
合併の株価効果と合併オプション価值・シナジー効果価値の関係についての実証分析

表 $1:$ 業種別合併実施企業の状況

\begin{tabular}{|c|c|c|c|c|}
\hline & \multicolumn{2}{|c|}{ 非グループ企業間 } & \multicolumn{2}{|c|}{ グループ企業間 } \\
\hline & $\begin{array}{l}\text { 買収 } \\
\text { 企業 }\end{array}$ & $\begin{array}{c}\text { 非買収 } \\
\text { 企業 }\end{array}$ & $\begin{array}{l}\text { 買収 } \\
\text { 企業 }\end{array}$ & $\begin{array}{c}\text { 非買収 } \\
\text { 企業 }\end{array}$ \\
\hline 建設業 & 4社 & 4 社 & 2社 & 1社 \\
\hline 食料品 & 3 社 & 3 社 & 1社 & \\
\hline 繊維製品 & & & 1社 & 2社 \\
\hline パルプ・紙 & 2 社 & 2社 & & \\
\hline 化学 & 4社 & 4社 & 1 社 & \\
\hline 医薬品 & 1社 & 1社 & & \\
\hline 石油・石炭製品 & 2 社 & 2社 & & \\
\hline ゴム製品 & & & 2社 & 1社 \\
\hline ガラス・土石製品 & 4社 & 4社 & & \\
\hline 鉄鋼 & & & 3 社 & 2 社 \\
\hline 非鉄金属 & & & 1社 & 2 社 \\
\hline 金属製品 & & & 1社 & 2 社 \\
\hline 機械 & 1社 & 1社 & 4 社 & 3 社 \\
\hline 電気機器 & 1社 & 1社 & 3社 & 2 社 \\
\hline 輸送用機器 & 1社 & 1社 & 3 社 & 1社 \\
\hline 精密機器 & & & 2社 & 2 社 \\
\hline その他製品 & & & 1社 & 1社 \\
\hline 海運業 & & & 2 社 & 2 社 \\
\hline 情報・通信業 & 1社 & 1社 & & \\
\hline 卸売業 & 3 社 & 3 社 & 1社 & 5 社 \\
\hline 小売業 & 2 社 & 2 社 & 2 社 & 2 社 \\
\hline 銀行業 & 1社 & 1社 & & \\
\hline 証券業 & 4社 & 4社 & & \\
\hline 保険業 & 1社 & 1社 & & \\
\hline その他金融業 & & & 1社 & \\
\hline 不動産業 & & & & 3 社 \\
\hline
\end{tabular}

さらに，モデルを推定するにあたって充分なデータが取れない取引もサンプルから除いた. その結果，本稿の分析サンプルは 66 取引となった. この内，非グループ企業同士の取引は 35 取引，グループ企業同士の合併は 31 取引である. 非グループ企業同士の合併取引はすべて同業 種間の合併となっている. グループ企業同士の合併取引のうち同業種間の合併が 18 取引, 異業 種間の合併が 13 取引となっている. 業種別 ${ }^{4}$ に合併取引をまとめたのが表 1 である. 取引所別 では表 2 の通りである. 非グループ企業同士の合併では, 東証 1 部の企業同士の合併が 20 取引 と最も多いのに対し，グループ企業同士の合併では，東証 1 部の企業同士の合併は 8 取引と少 なく, 東証 1 部上場企業とそれ以外の取引所に上場している企業の合併取引が 21 取引となった. 表 1 および表 2 から，グループ企業同士の合併はグループの製販統合や生産統合などコスト低 減に主眼を置いた合併が多いのに対して, 非グループ企業同士の合併は規模の経済に主眼を置

4 東証 33 業種分類に基づき分類した. 
表 2 : 取引所別の合併実施企業の状況

\begin{tabular}{|l|c|c|c|c|}
\hline \multirow{2}{*}{} & \multicolumn{2}{|c|}{ 非グループ企業間 } & \multicolumn{2}{|c|}{ グループ企業間 } \\
\cline { 2 - 5 } & 買収企業 & 非買収企業 & 買収企業 & 非買収企業 \\
\hline 東京証券取引所1部 & 28社 & 20社 & 29社 & 8社 \\
\hline 東京証券取引所2部 & 3社 & 4社 & 2社 & 社 \\
\hline 大阪証券取引所1部 & & 1社 & & \\
\hline 大阪証券取引所2部 & 1社 & 5社 & & 5 社 \\
\hline 名古屋証券取引所2部 & & & & 3 社 \\
\hline ジャスダック市場 & 2社 & & & 社 \\
\hline 店頭市場 & 1社 & 5社 & & \\
\hline
\end{tabular}

いた合併であることが読み取れる.

個々の取引については，レコフ編 [36]の『日本企業の M\&A データブック5』及び日経テレコ ン2 1 に掲載されている情報をもとに，有報 Netに登録されている上場企業の有価証券報告書 により確認を行った．株価情報並びに合併発表の 1 年前から取引完了までの期間の発行済み株 式数の増減についてはNEED S株式データベースより収集した. 合併アナウンスメント日に ついては，日経テレコン 21 の発表日を取引日とした. 尚, 合併アナウンスメントが株式の取引 日終了後や休日に行われている場合には，アナウンスメント日翌日を現在時点として分析を行 つた.

\section{2 分析結果}

本項では，まず，イベント・スタディによる合併の株価効果について述べ，次に合併の株価 効果を合併オプション価值とシナジー効果価值により分析する. 合併の株価効果の計測並びに 合併オプション価值とシナジー効果価值による合併の株価効果の分析では，合併をグループ企 業同士の合併か, 非グループ企業同士の合併に分けて行う.

\subsection{1 合併の株価効果}

イベント・スタディにより合併アナウンスメント日前後の合併の株価効果をグループ企業同 士の合併と非グループ企業同士の合併に分けて分析する. 表 3 は累積異常収益率及び日次の異 常収益率に関する検定結果である.また，合併アナウンスメント日前後の異常収益率と累積異 常収益率の変動を示したのが図 1 である.

表 3 の検定の結果，非グループ企業同士の合併，グループ企業同士の合併ともに，合併アナ ウンスメント当日までの累積異常収益率が統計的有意に正となっている. しかも，合併アナウ ンス日の 3 日前から株式時価総額がすでに上昇し始めている. このことは，投資家が事前に合

5 データの出典は，日本経済新聞，日経金融新聞，日経産業新聞，日経流通新聞の日経 4 紙に加え，一 般紙，地方紙，専門紙，ニュース・リリースなどである. 
合併の株価効果と合併オプション価值・シナジー効果価値の関係についての実証分析

表 3 : 合併アナウンスメントに対応する異常収益率

\begin{tabular}{|c|c|c|c|c|c|c|c|c|}
\hline $\begin{array}{l}\text { イベント } \\
\text { 日 }\end{array}$ & $\begin{array}{c}\text { 累積異常 } \\
\text { 収益率 } \\
\text { (非グルー } \\
\text { プ企業間) }\end{array}$ & $\begin{array}{l}\text { J検定 } \\
\text { 統計量 }\end{array}$ & $\begin{array}{l}\text { 累積異常 } \\
\text { 収益率 } \\
\text { (グルーフ } \\
\text { 企業間) }\end{array}$ & $\begin{array}{l}\text { J検定 } \\
\text { 統計量 }\end{array}$ & $\begin{array}{c}\text { 異常 } \\
\text { 収益率 } \\
\text { (非グルー } \\
\text { プ企業間) }\end{array}$ & $\begin{array}{l}\text { J検定 } \\
\text { 統計量 }\end{array}$ & $\begin{array}{c}\text { 異常 } \\
\text { 収益率 } \\
\text { (グループ } \\
\text { 企業間) }\end{array}$ & $\begin{array}{l}\text { J検定 } \\
\text { 統計量 }\end{array}$ \\
\hline-3 & 0.0088 & 2.1655 & 0.0074 & 1.7943 & 0.0088 & 2.1655 & 0.0074 & 1.7943 \\
\hline-2 & 0.0246 & 4.2812 & 0.0111 & 1.8997 & 0.0158 & 3.8989 & 0.0037 & 0.8978 \\
\hline-1 & 0.0464 & 6.5707 & 0.0110 & 1.5365 & 0.0218 & 5.3666 & -0.0001 & -0.0220 \\
\hline 0 & 0.0485 & 5.9419 & 0.0193 & 2. 3226 & 0.0021 & 0.5207 & 0.0083 & 2.0016 \\
\hline 1 & 0.0305 & 3.3332 & 0.0129 & 1.3919 & -0.0180 & -4.4302 & -0.0063 & -1.5340 \\
\hline 2 & 0.0153 & 1.5233 & 0.0136 & 1.3326 & -0.0152 & -3.7468 & 0.0007 & 0.1594 \\
\hline 3 & 0.0131 & 1.2081 & 0.0040 & 0.3624 & -0.0022 & -0.5341 & -0.0096 & -2.3240 \\
\hline
\end{tabular}

注：正規分布において、1\%、5\%、10\%有意点の絶対值はそれぞれ、2.576、1.960、1.645である。

図 1 : 累積異常収益率の変動

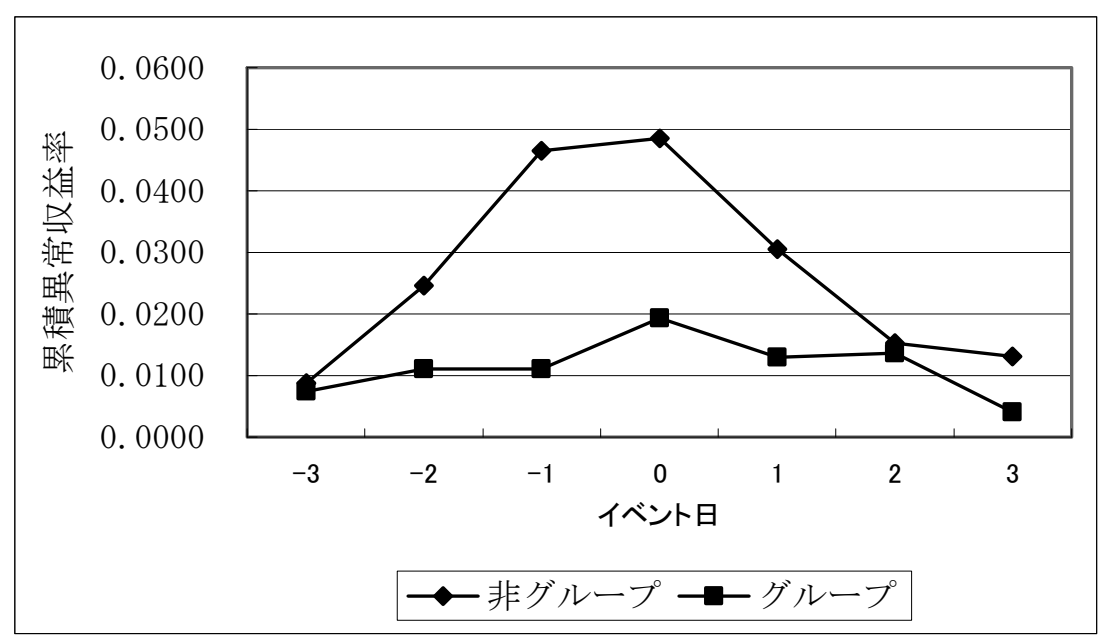

表 $4:$ 累積異常収益率の平均の差の検定

\begin{tabular}{|r|r|r|r|r|}
\hline & 非グループ企業間 & グループ企業間 & 両グループの差 & \multicolumn{1}{c|}{ t值 } \\
\hline $\begin{array}{c}\text { イベント日までの } \\
\text { 累積異常収益率 }\end{array}$ & 0.0485 & 0.0193 & 0.0293 & 1.8161 \\
\hline
\end{tabular}

併するということをある程度予測している可能性があると考えられる. 図 1 から, 非グループ 企業同士の合併のほうが，グループ企業同士の合併に比べて株式時価総額に与える影響が大き いことが読み取れる.このことを検定した結果が表 4 である. 表 4 の検定結果, その差は統計 的に有意であることが示されている. 非グループ企業同の合併アナウンスメント効果に関して は，合併という戦略に対して概ね株式市場が良好な反応を示していることの表れであり，合併 の効果，つまり将来の収益拡大期待や成長期待などが株価に大きく影響を与えていると解釈す 
ることができる，グループ企業同士の合併アナウンスメント効果に関しては，株式市場は個別 企業の株式を評価するのではなく，既にグループ企業との関連性で株式を評価していることの 表れであり，事業体制の見直し等のグループ内の経営戦略，事業戦略の变更に伴う事業資源や 経営資源の統合によるコスト低減期待や経営効率の向上期待などが株価に一定の影響を与えて いるという結果を示すものである.

3.2.2 合併の株価効果と合併オプション価值およびシナジー効果価值の関係

前の節は，グループ企業同士の合併及び非グループ企業同士の合併における合併の株価効果 の平均值について比較分析した. 本項では, その株価効果とオプション価格及びシナジー効果 との関係を計量的に検証する.

検証にあたっては，以下のモデルを立てて，分析を行う。

$$
C A R_{i}=\alpha_{0}+\alpha_{1} \times \text { option__value }_{i}+\alpha_{2} \times \text { synerg }_{i}+\varepsilon_{i}
$$

ここで，CAR $R_{i}$ は合併アナウンスメント日までの合併取引 $i$ の累積異常収益率である. $\alpha_{0}$ は 定数項を, $\alpha_{1}$ は合併オプション価值係数を， $\alpha_{2}$ はシナジー効果価值係数を， $\varepsilon_{i}$ は誤差項をそ れぞれ表している.（17)式の分析結果は表 5 の通りである.

表 5 より，非グループ企業同士の合併においては，累積異常収益率が合併オプション価值と 有意水準 5\%で統計的に有意な関係を持っているが，シナジー効果価值とは統計的に有意な関係 を持っていないとの結果を得た，一方，グループ企業同士の合併においては，合併オプション 価值もシナジー効果価值も異常収益率に統計的に有意な影響を与えていないとの結果を得た. しかし，統計的には有意ではないがシナジー効果価值よりも合併オプション価值のほうが異常 収益率に対して影響を与える傾向があることが表 5 より読み取れる.つまり，合併のアナウン スメントの株価効果には，シナジー効果価值よりもむしろ合併オプション価值のほうが影響を 与えていると考えられる.

これらの結果から，非グループ企業同士の合併においては，異なる経営資源の統合や分野の 異なる事業の再編等より，将来の成長機会に対する期待の大きさを反映する合併オプションが 累積異常収益率に有意な影響を与えていると考えられる. 一方，株式市場では，グループ企業 同士の合併においては，合併する企業の各々の株式は既にグループ企業として評価されている ことから,グループ内の事業再編や戦略変更等に伴う合併では, 合併オプション価值やシナジ

表 5 : 累積異常収益率と合併オプション価值，シナジー効果価值の関係

\begin{tabular}{|c|c|c|c|c|}
\hline 合併種類 & 説明変数 & 係数 & 標準偏差 & $\mathrm{P}$ 值 \\
\hline \multirow{3}{*}{ 非グループ企業間 } & シナジー効果価值 & 0.01909 & 0.01539 & 0.22400 \\
\hline & オプション価值 & 0.00006 & 0.00003 & 0.04600 \\
\hline & 定数項 & -0.00773 & 0.01607 & 0.63400 \\
\hline \multirow{3}{*}{ グループ企業間 } & シナジー効果価值 & 0.00446 & 0.01667 & 0.79100 \\
\hline & オプション価值 & 0.00002 & 0.00001 & 0.11900 \\
\hline & 定数項 & -0.00709 & 0.00882 & 0.42900 \\
\hline
\end{tabular}


合併の株価効果と合併オプション価值・シナジー効果価値の関係についての実証分析

一効果価值は株価収益率にほとんど影響を与えないことから株主価值増大に貢献しないと考え られる。

\section{4 まとめ}

本稿では，合併取引そのものに対する株式市場の反応をグループ企業同士の合併と非グルー プ企業同士の合併に分けて計測し，さらに，合併アナウンスメント時点での合併オプションの 価值と合併後のシナジー効果の価值により分析を行った．具体的には，まず，合併する企業の 株式時価総額の合計額を用いて，イベント・スタディにより合併アナウンスメント日における 株主価值への影響, すなわち異常収益率を算出した. 次に, 合併する企業の合併アナウンスメ ント日以前の株式時価総額の合計額を用いて，マーケットモデルにより合併が無いと仮定した 場合の合併実施時点における株式時価総額を推定し，この推定した株式時価総額を行使価格， 合併発表後の 2 つ企業の株式時価総額の合計額を原資産として，リアルオプション・アプロ 一チを用いて合併オプションの価值を算出した．さらに，合併実施後に統合してできた企業の 株式時価総額とマーケットモデルにより推定した合併が無いと仮定した場合の合併実施時点

（上場廃止時点）における株式時価総額からシナジー効果の価值を算出する. 最後に，算出さ れた合併オプションの価值とシナジー効果の価值を用いて，合併アナウンスメント日時点での 株主価值への影響を分析した.

分析の結果，まず，イベント・スタディによる分析では，合併のアナウンスメントに対して， 株式市場は統計的有意な正の反応を示していることが確認できた. その中でも, 非グループ企 業同士の合併はグループ企業同士の合併よりアナウンスメントに対する市場の反応が大きいこ とが確認できた. 次に, 合併オプションの価值とシナジー効果の価值がアナウンスメント効果 に影響を与えているかどうかについて分析を行い，シナジー効果の価值はアナウンスメント効 果に統計的有意な影響を与えていないが，非グループ企業同士の合併において，合併オプショ ン価值とアナウンスメント効果の間に統計的に有意かつ正の関係があることが確認できた.

これらの結果から，非グループ企業同士の合併に対するアナウンスメント効果については, 異なる経営資源の統合や分野の異なる事業の統合等, 合併による将来の成長機会の価值が市場 にある程度反映されていると言える. 一方，グループ企業同士の合併に対するアナウンスメン 卜効果については，グループ内の事業再編や戦略変更等による効果よりもむしろ親子上場の見 直しによるグループの資本政策の変更等, 他の要因が評価されていると推測される.

尚，仮に合併がない場合の行使価格の推定に関してはデータの制約上マーケットモデルを用 いて行った. 昨今ではこのような推定にはよくファーマ・フレンチモデル等が用いられている が，この点に関してはデータ収集とあわせ，今後の課題としたい. また，新設合併・吸収合併 の差異，持株会社形態など，合併形態の違いによる経済効果の差異についてもデータ収集とあ わせ，今後の課題としたい。 さらに，本稿の使用データの期間において，M\&A に関し商法の 大きな改正が行われている. これら制度変更が合併に与える影響についても今後の課題とした い. 


\section{謝辞}

本論文の作成にあたり，砂川伸幸氏（神戸大学）ならびに 2 名の匿名レフリーから非常に有 益なコメントを頂いた。 ここに記して感謝する，もちろんありうべき誤謬は筆者らに帰すもの である。

\section{参考文献}

[1] Amihud, Y. and B. Lev. (1981). Risk Reduction as a Managerial Motive for Conglomerate Mergers .Bell Journal of Economics, 12, 605-617.

[2] Andrade, G., M. Mitchell and E. Stafford. (2001). New Evidence and Perspectives on Mergers. Journal of Economic Perspectives, 15, 103-120.

[3] Berkovitch, E. and M. P. Narayanan. (1993). Motives for Takeovers : An empirical Investigation. Journal of Financial and Quantitative Analysis, 28, September, 347-362.

[4] Betton, S., and P. Moran. (2003). A Dynamic Model of Corporate Acquisitions. Papers, $7^{\text {th }}$ Annual International Real Options Conference.

[5] Black, F. and Scholes, M. (1973). The pricing of options and corporate liabilities. Journal of Political Economy, 81, 637-659.

[6] Bradlley, M., A. Desai and E. H. Kim. (1983) The Rationale Behind Interfirm Tender Offers : Information or Synergy?. Journal of Financial Economics, 11, 183-206.

[7] Bradlley, M., A. Desai and E. H. Kim. (1988) Synergistic Gains from Corporate Acquisitions and Their Division Between the Stockholders of Target and Acquiring Firms. Journal of Financial Economics, 21, 3-40.

[8] Campbell, J. Y., A. W. Lo and A. C. MacKinlay. (1997). The Econometrics of Financial Markets, Princeton: Princeton University Press.

[9] Carr, P. (1995). The Valuation of American Exchange Options with Application to Real Options. In Real Options in Capital Investments : Models, Strategies, and Applications, ed. L. Trigeorgis, Praeger., 109-120.

[10]Dunis C. L. and Til Klein. (2005). Analysing mergers and acquisitions in European financial services : An application of real options. The European Journal of Finance, 11 , 339-355.

[11]Haugen, R.A. and T.C. Langentieg. (1975). An Empirical Test for Conglomerate Merger. Journal of Finance, 30, 521-537.

[12]Higgins, R.C. and L.D.Schall. (1975). Corporate Bankruptcy and Conglomerate Merger. Journal of Finance, 30, 93-113.

[13]Jarrell, G., J. Brickley and J. Netter. (1988). The Market for Corporate Control : The Empirical Evidence Since 1980. Journal of Economic Perspectives, 2, 49-68.

[14]Jensen, M.C. (1986). Agency Costs of Free Cash Flow, Corporate Finance, and Takeovers Ameican Economic Review, 76, 323-329.

[15]Kang, J., A. Shivdasani and T. Yamada. (2000). The Effect of Bank Relations on Investment 
Decisions : An Investigation of Japanese Takeover Bids. Journal of Finance, 55, 2197-2218.

[16]Lambrecht, B.M. (2004). The Timing and Terms of Mergers Motivated by Economies of Scale. Journal of Financial Economics, 72, 41-62.

[17]Lang, L.H.P., R.M.Stulz and R.A.Walkling. (1989). Managerial Performance, Tobin's q, and the Gains from Successful Tender Offers. Journal of Financial Economics, 24, 137-154

[18]Levy, H. and M. Sarnat, (1970). Diversification, Portfolio Analysis and the Uneasy Case for Conglomerate Mergers. Journal of Finance, 25, 795-802.

[19]Lewellen, W.G., (1971). A Pure Financial Rationale for the Conglomerate Merger. Journal of Finance, 26, 521-537.

[20]Mann, S.V. and N.W.Sicherman. (1991). The Agency Costs of Free Cash Flow : Acquisition Activity and Equity Issues. Journal of Business, 64, 213-227.

[21]Margrabe, W. (1978). The value of an option to exchange one asset for another. Journal of Finance, 33, 177-186.

[22]McDonald, R. and D. R. Siegel. (1985). Investment and valuation of firms when there is an option to shut down. International Economic Review, 26, 331-349.

[23]Morck, R., A. Shleifer and R.W.Vishny. (1990). Do Managerial Objectives Drive Bad Acquisitions? . Journal of Finance, 45, 31-48.

[24]Morellec, E. and A. Zhdanov. (2005). The dynamics of mergers and acquisitions. Journal of Financial Economics, 77, 649-672.

[25]Mulherin , J. H., and A. L. Boone. (2000). Comparing Acquisitions and Divestitures. Journal of Corporate Finance, 6, 117-139.

[26]Okawa, M., and M. Tsujimura. (2009). The value of a merger and its optimal timing. Applied Financial Economics, forthcoming

[27]Roll, R. (1986). The Hubris Hypothesis of Corporate Takeovers Journal of Business, 59, 197-216.

[28]Servaes, H.(1991). Tobin's Q and the Gains from Takeovers. Journal of Finance, 46, 409-419.

[29]Shleifer, A., and R. M. Vishny. (1989). Management Entrenchment : The Case of Manager-Specific Investment Journal of Financial Economics, 25, 123-139.

[30]Smith, K.W. and A.J. Triantis. (1995). The Value of Options in Strategic Acquisitions. in Real options in Capital Investments : Models, Strategies, and Applications, edited by L. Trigeorgis, Westport, Conn. : Praeger, 135-149.

[31]Yeh, T. and Y. Hoshino. (2001). Shareholders' Wealth, Bank Control, and Large Shareholders : An Analysis of Japanese Mergers. Japan Journal of Finance, (『経営財務研究』), 21, 150-166.

[32]井上光太郎 (2002). “日本の M\&A における取引形態と株価効果”.「経営財務研究」 22, 107-120.

[33]井上光太郎・加藤英明 (2003). “M\&A 発表日の株価効果に関する要因分析”.「現代ファイナ ンス」 13, 3-28.

[34]大川雅也・辻村元男 (2004). “リアルオプション・アプローチを用いた日本企業の合併に関 


\section{大川雅也・馬 文傑}

する実証分析”「大阪大学経済学」54,168-184.

[35]大川雅也 (2005). “リアルオプション・アプローチを用いた日本の金融機関統合に関する実 証分析”「国際金融」1144, 34-39.

[36]レコフ編(2003). “日本企業の M\&A データブック” 